\section{Om faget geriatri - et grunnlag for viten}

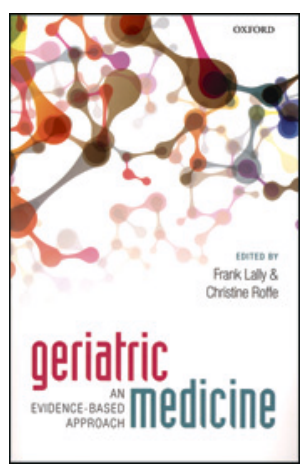

Frank Lally, Christine Roffe, red. Geriatric medicine

An evidence-based approach. 221 s, tab, ill.

Oxford: Oxford University Press, 2014

Pris GBP 25

ISBN 978-0-19-968964-4

Boken er ikke en lærebok i geriatri i egentlig forstand. Den er mer en bok som gir innblikk i hva faget står for, både hvordan det har utviklet seg, fra Marjory Warren publiserte sin artikkel i 1943, til situasjonen i dag hvor faget særlig omfatter akutt sykdom hos skrøpelige eldre, og alle de forhold som er avgjørende for et best mulig liv $i$ alderdommen.

De 16 kapitlene er skrevet av forskjellige forfattere, og teksten er selvsagt preget av dette. De har lagt vekt på hva som er dokumentert i forskning, og det er mange «bokser» eller rammer med nøkkelpunkter. Hvert kapittel har en oppsummering/konklusjon. Det er vist til aktuelle nettsider for hvert kapittel, med henvisning til retningslinjer der dette finnes. Videre er det et vell av referanser, noen steder opp mot 100 bare for ett kapittel, f.eks. i kapitlet om urininkontinens s. 96.

Boken er dedikert til professor Peter Crome som har vært inspirator for de ansvarlige redaktørene, Frank Lally og Christine Roffe.

Målgruppen er særlig dem som har faglig bakgrunn, og som er involvert $\mathrm{i}$ utviklingen av helsetjenester for gamle, både spesialisthelsetjeneste og kommunehelsetjeneste. Målet er å gi «bakgrunn for tenking innen geriatri, gi innsyn i forskning på området og anvise kilder for aktuell informasjon, samt peke på ubesvarte spørsmål».

Jeg synes boken langt på vei oppnår siktemålet. Kapitlene er ujevne, fra lærebokpreget oversikt, f.eks. om urininkontinens, til kapitlet om demens hvor man kun omtaler hukommelsesklinikker. I et eget kapittel diskuterer man begrepet «frailty», som vi vel helst oversetter til «skrøpelighet». Akutt slag og viderebehandling er geriatri i Storbritannia, og det er gode grunner for at dette også kunne være hensiktsmessig andre steder.

Flere steder er det understreket at gamle mennesker er underrepresentert i klinisk forskning, og det anbefales å ta tak i dette forholdet. Eldre mennesker bør også i større grad være med på planlegging og design av studier. De to siste kapitlene omhandler dette. Det kan være grunnen til at noen av anbefalingene hviler på et noe tynt grunnlag, for eksempel behandling med medikamenter for depresjon i høy alder.

Jeg anbefaler ikke boken som lærebok for studenter, men som grunnlag for refleksjon og innsikt hos fagfolk som planlegger og leder organisering av helsetjenester for eldre, f.eks. byråkrater og direktører.

\section{Sigurd Sparr}

Overlege, Geriatrisk avdeling

Universitetssykehuset Nord-Norge

\section{Voldshandlinger og moral}

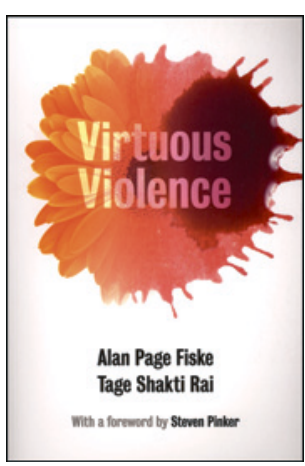

Alan Page Fiske, Tage Shakti Rai

Virtuous violence

Hurting and killing to create, sustain, end, and honor social relationships. $357 \mathrm{~s}$, tab, ill. Cambridge: Cambridge University Press, 2014. Pris GBP 17

ISBN 978-1-107-45891-8

Hvordan motiveres bruk av vold og tortur? Hva er det som får ellers gode og omsorgsfulle mennesker til å skade og drepe andre og seg selv? Og hvorfor er det ofte folk vi kjenner som volden rettes mot? Det er vanlig å tenke at dette er et uttrykk for vår «dyriske» natur som bryter igjennom, at bruk av vold er en manifestasjon av en iboende ondskap.

Forfatterne har kommet frem til den motsatte oppfatning. Når mennesker skader og dreper noen, gjør de det fordi de føler at bruk av vold og tortur er nødvendig og riktig. Volden er moralsk motivert. Det handler om å gjenopprette og vedlikeholde sosiale relasjoner slik som de bør være ut fra voldsutøverens kultur og oppfatning. Motivene for bruk av vold springer ofte ut fra at det er en sosial relasjon mellom utøver og offer, en relasjon som det er nødvendig å forsvare når den er truet, eventuelt gjennom grusomme handlinger, og ofte med eget liv som innsats.

Den største delen av boken viser resultater av forfatternes egne studier. De har systematisk samlet inn eksempler på menneskers voldelige atferd rundt om i verden over lange tidsperioder. Det er ikke lystelig lesning. Eksempler er voldtekt og gruppevoldtekt, etnisk vold, religiøst begrunnet grusomhet, bruk av «rensende» ild, aztekernes hjerteekstirpasjoner, Tudor-dynastiets og japanernes straffemetoder, vold mot barn osv. Det er overraskende å se at lord Nelson var en så brutal person. Han sparte ikke på pisking og henging.

For at terrorhandlinger skal ha moralsk mening blir det feil å dehumanisere ofrene. For voldsbrukerne er det nødvendig at ofrene er fullt ut i stand til å føle smerte, ydmykelse, redsel og dødsangst. I slike tilfeller er ikke terroristene disengasjert - de er moralsk engasjert. Og ofrene er ikke dehumanisert, men humanisert. Voldsbrukerne vil ofte se sine motstandere som fullt ut menneskelige. Etter forfatternes teori er det derfor de fortjener å bli utsatt for uhyrlige handlinger.

Hvorfor forlanger det religiøse overhodet $\mathrm{i}$ de aller fleste religioner at mennesker skal drepe? Hvor får profetene denne ideen fra? Svaret er rimelig nok at religiøse ledere og deres følgere projiserer sine egne moralske motiver og følelser på gudene. Mennesker forestiller seg at gudene har de samme følelser som de selv erfarer. Så hver profetisk åpenbaring eller religiøs tekst som forlanger voldsbruk, er uttrykk for menneskers egne moralske motiver. Guds moral blir en modell for menneskets moral og motiverer tilsvarende voldsbruk.

Det er ikke lett å forstå fullt ut hvordan de oppgitte voldseksemplene i denne boken understøtter forfatternes «Virtuous violence theory». I mange tilfeller virker den mangelfull. Men uansett må det være av betydning å analysere årsaker til menneskers brutalitet. Ved å studere denne siden av menneskelig atferd kan man håpe å få kunnskaper om det fenomenet som vanligvis kalles ufattelig grusomhet. Det kan kanskje bidra til å forebygge de verste utskeielsene i fremtiden.

\section{Anton Hauge}

Professor emeritus i fysiologi

Oslo 